\title{
PENGARUH KEPUASAN DAN LOYALITAS PELANGGAN TERHADAP WORD OF MOUTH PADA PELANGGAN PRODUK XL AXIATA DI KECAMATAN BULELENG
}

\author{
L.A Pratiwi ${ }^{1}$, N.L.W.S. Telagawathi ${ }^{2}$ \\ 1,2Jurusan Manajemen, Universitas Pendidikan Ganesha, Singaraja \\ e-mail: pratiwiadeiluh@gmail.com, gemilangsuryawan@gmail.com
}

\begin{abstract}
Abstrak
Penelitian ini bertujuan untuk menguji pengaruh dari kepuasan dan loyalitas pelanggan terhadap word of mouth pada pelanggan produk XL Axiata di Kecamatan Buleleng baik secara simultan maupun parsial. Rancangan penelitian yang digunakan adalah penelitian kuantitatif kausal. Sampel dalam penelitian ditentukan dengan menggunakan teknik purposive sampling. Jumlah sampel yang digunakan sebanyak 100 responden. Pengumpulan data menggunakan instrumen kuesioner dan teknik analisis data yang digunakan adalah analisis regresi linier berganda. Hasil penelitian ini adalah: (1) Kepuasan dan loyalitas pelanggan secara simultan memiliki efek baik dan signifikan terhadap word of mouth. (2) Kepuasan pelanggan memberikan efek yang positif dan signifikan terhadap word of mouth. (3) Loyalitas pelanggan memiliki efek yang poitif dan signifikan terhadap word of mouth.
\end{abstract}

Kata kunci : kepuasan pelanggan, loyalitas pelanggan, word of mouth

\begin{abstract}
This study aims to examine the effect of customer satisfaction and loyalty on word of mouth on $X L$ Axiata product customers in Buleleng District, either simultaneously or partially. The research design used was causal quantitative research. The sample in the study was determined using purposive sampling technique. The number of samples used was 100 respondents. Collecting data using a questionnaire instrument and the data analysis technique used is multiple linear regression analysis. The results of this study are: (1) Customer satisfaction and loyalty simultaneously have a good and significant effect on word of mouth. (2) Customer satisfaction has a positive and significant effect on word of mouth. (3) Customer loyalty has a positive and significant effect on word of mouth.
\end{abstract}

Keywords : customer loyalty, customer satisfaction, word of mouth

\section{Pendahuluan}

Penggunaan gadget dewasa ini seperti laptop, smartphone, tablet, notebook dan lainnya sudah menjadi kebutuhan manusia dalam melengkapi gaya hidupnya. Hal ini disebabkan karena adanya berbagai fitur-fitur menarik pada aplikasi sosial media serta perkembangan browser yang semakin canggih, sehingga mempermudah untuk mencari informasi dan hiburan diwaktu senggang. Peningkatan kebutuhan manusia akan sosial media dan internet pastinya akan memerlukan dukungan sim card yang memiliki jaringan serta paket data internet terbaik. Salah satu produk sim card yang dikenal masyarakat adalah XL Axiata. Sebagai perusahaan penyedia layanan telekomonikasi di Indonesia, PT $\mathrm{XL}$ Axiata Tbk terus mengembangkan inovasinya meluncurkan jaringan 4.5G pada spectrum $1800 \mathrm{MHZ}$.

Berdasarkan data Top Brand Index (TBI) dari tahun 2018, 2019 dan 2020 pada fase 1, XL Axiata tetap menduduki peringkat ke 3. Namun XL Axiata mengalami penurunan disetiap tahunnya. Pada tahun 2018 persentase pengguna XL Axiata sebesar 12,7\% sedangkan tahun 2019 persentase pengguna XL Axiata sebanyak 12,0\%. Sehingga pada tahun 2018 sampai 2019 mengalami penurunan sebanyak 0,7\%. Pada tahun 2020 persentase pengguna XL Axiata sebanyak 11,5\%. Sehingga pada tahun 2019 sampai tahun 2020 XL Axiata mengalami penurunan sebanyak $0,5 \%$ walaupun mengalami penurunan lebih sedikit dari tahun sebelumnya, namun apabila terjadi secara berkelanjutan, tentu akan mempengaruhi tingkat pendapatan dan kepercayaan merek terhadap produk XL Axiata. Hal ini menandakan bahwa kemungkinan para pelanggan memiliki lebih dari satu produk sim card, sehingga para pelanggan juga menggunakan produk pesaing sebagai pendukung apabila sim card yang 
satu sedang mengalami masalah. Kondisi ini diduga akibat rendahnya kinerja XL Axiata yang tidak sesuai dengan yang diiklankan (Sudarso, 2018).

Penyebab terjadinya penurunan pada produk XL Axiata ini diduga karena rendahnya tingkat penyebaran rekomendasi positif yang dilakukan dari mulut ke mulut atau terjadinya penyebaran rekomendasi yang negative melalui word of mouth. Menurut Joesyana (2018) word of mouth dikenal sebagai kegiatan pemasaran yang paling efektif. Guna membentuk penyebaran informasi atau pengalaman terkait produk atau jasa yang dimanfaatkan melalui word of mouth, dapat dilakukan dengan jalan menciptakan kepuasan dan loyalitas pelanggan. Menurut Rahmawati (2014) menyatakan bahwa kepuasan dan loyalitas pelanggan merupakan salah satu dasar utama yang membentuk penyebaran word of mouth. Pernyataan tersebut didukung oleh penelitian yang dilakukan Titing (2020) dengan hasil yang menyatakan bahwa adanya pengaruh yang positif dan signifikan pada kepuasan dan loyalitas pelanggan terhadap word of mouth. Menurut Irawan (dalam Kristianto, 2011:32) pelanggan yang merasa puas terhadap produk atau jasa yang dipilih dapat meningkatkan keinginan pelanggan itu sendiri untuk menyebrkan rekomendasi secara word of mouth sehingga mampu menarik calon pelanggan baru. Sejalan dengan pernyataan tersebut Anita, dkk (2015) menyatakan hasil penelitiannya yaitu kepuasan pelanggan terhadap word of mouth memiliki pengaruh yang positif dan signifikan terhadap. Selain menciptakan kepuasan pelanggan dalam mempertahankan persaingan perusahaan juga perlu mempertahankan pelanggan yang loyal. Perilaku pelanggan yang loyal dapat dikategorikan apabila pelanggan tersebut tetap setia membeli produk atau jasa yang dipilih dan melakukan pembelian ulang secara konsisten dan dalam jangka waktu yang lama sehingga dapat memicu pelanggan tersebut melakukan rekomendasikan terkait produk atau jasa yang dipilihnya kepada orang lain (Oliviana, dkk, 2017). Pernyataan tersebut didukung oleh Rahmawati, dkk (2014) yang menyatakan hasil penelitiannya bahwa loyalitas memberikan pengaruh yang positif dan signifikan terhadap word of mouth. Namun, terdapat beberapa penelitian terdahulu mengenai word of mouth yang hanya mencantumkan loyalitas pelanggan sebagai penentu terciptanya word of mouth. Seperti penelitian yang dilakukan oleh Anggita (2019) yang menyatakan kepuasan pelanggan terhadap word of mouth memiliki pengaruh yang positif tetapi tidak signifikan. Sedangkan penelitian lain mencantumkan bahwa loyalitas pelanggan hanya sebagai mediasi yang menghubungkan antara kepuasan pelanggan terhadap word of mouth. seperti hasil penelitian lainnya yang dilakukan oleh Liao, dkk (2010) menyatakan kepuasan pelanggan dapat mempengaruhi word of mouth melalui loyalitas pelanggan.

Bali merupakan daerah tujuan wisata yang popular di Indonesia bahkan sampai mendunia. Hal ini berarti Bali membutuhkan ketersediaan jaringan data yang kuat untuk memberikan informasi dan pengalaman mengenai keelokan alam dan budaya Bali di jejaring sosial. Menurut Setyawan (dalam Dewi, Balipost, 2019) menyatakan bahwa selain menunjang sektor pariwisata, jaringan data yang kuat juga akan mendukung aktivitas masyarakat Bali disektor penting lainnya, seperti sektor perekonomian, sektor kesehatan dan sektor pendidikan khususnya Kabupaten Buleleng. Menurut Ibnu (dalam Sukarelawanto, Bisnis.com, 2019) menyatakan bahwa Kabupaten Buleleng pada Provinsi Bali mengalami kenaikan trafik komonikasi tertinggi pada akhir tahun 2019. Kondisi ini disebabkan karena kesadaran masyarakat baik dari area perkotaan ataupun pedesaan dalam memanfaatkan layanan data guna mendukung aktivitas kesehariannya. Khususnya Kecamatan Buleleng yang merupakan pusat pemerintahan di Kabupaten Buleleng.

Kajian pustaka dalam penelitian ini menjelaskan teori mengenai kepuasan pelanggan, loyalitas pelanggan dan word of mouth. Kristianto (2011) menyatakan definisi word of mouth merupakan pernyataan yang disampaikan mengenai pengalamannya dalam pemanfaatan suatu produk atau jasa oleh orang lain selain organisasi pada perusahaan tersebut kepada pelanggan dan dilakukan baik secara personal maupun non personal. Sedangkan Finanda, dkk (2017) menyatakan pengertian word of mouth sebagai komunikasi yang dilakukan dalam rangka menyampaikan informasi mengenai pengalamannya terhadap suatu produk atau jasa tertentu kepada orang lain. Promosi yang disampaikan melalui word of mouth memberikan hasil yang baik. Promosi yang disampaikan biasanya mengandung pujian, rekomendasi, kepercayaan dan keyakinan untuk menarik konsumen lain. ( Fitriyati, 2017). Sesuai dengan 
pendapat beberapa para ahli atas terkait pengertian word of mouth dapat ditarik kesimpulan bahwa word of mouth merupakan pernyataan yang disampaikan kepada orang lain baik dilakukan secara lisan, tulisan maupun media internet mengenai pengalaman pribadi terhadap suatu produk, jasa dan merek tertentu untuk menarik calon pelanggan baru. Adapun dimensi word of mouth menurut Joysiana (2018) yaitu sebagai berikut. (1) talkers, (2) topik, (3) Alat, (4) partisipasi, (5) tracking. Sedangkan indikatornya menurut Berry (2015) sebagai berikut. (a) konsumen membicarakan hal positif terhadap produk atau jasa yang ditawarkan. (b) konsumen dapat merekomendasikan pengalamannya mengenai pemanfaatan produk dan jasa. (c) memberikan dorongan atau motivasi untuk menarik calon pelanggan.

Tjiptono (2012 : 55) memaparkan bahwa kepuasan pelanggan merupakan konsep dasar mengevaluasi apakah kinerja suatu produk pada bisnis mampu melampaui harapan pelanggan. Kepuasan pelanggan adalah mengevaluasi antara persepsi atau harapan terhadap hasil kinerja suatu produk yang mengakibatkan munculnya perasaaan seseorang baik perasaan senang ataupun kecewa setelah mengkonsumsi atau memakai produk atau jasa tertentu (Kotler, 2012 : 13). Sedangkan menurut Gerson (2010 : 293) kepuasan pelanggan adalah perasaan pelanggan apabila harapannya tehadap produk atau jasa dapat terlampaui. Berdasarkan pengertian menurut beberapa ahli diatas dapat disimpulkan bahwa kepuasan pelanggan merupakan konsep penting untuk menjalankan bisnis dan manajemen yang menjelaskan mengenai persepsi pelanggan terhadap terpenuhinya harapan pelanggan atas penggunaan produk atau jasa tertentu. Adapun lima dimensi yang mempengaruhi kepuasan pelanggan menurut Irawan (2008:37) sebagai berikut. (1) kualitas produk, (2) kualitas pelayanan (service quality), (3) emotional factor, (4) harga, (5) biaya. Sedangkan indikatornya Menurut Widiyanesti, dkk (2016) sebagai berikut. (a) kepuasan pelanggan keseluruhan, (b) penilaian pelanggan, (c) konfirmasi harapan, (d) minat melakukan pembelian secara berulang, (e) kesediaan untuk merekomendasi.

Menurut Fleming (2016 : 34) loyalitas pelanggan merupakan keputusan pelanggan dan perilaku pelanggan dalam menggunakan suatu produk atau jasa tertentu secara tetap dan berulang. Pengertian loyalitas pelanggan menurut Kotler, dkk (2012) adalah situasi konsumen yang tetap setia membeli dan memanfaatkan produk baik berupa barang atau jasa pada pada satu perusahaan dengan membelanjakan seluruh anggaran yang dimilikinya. Sedangkan Griffin ( 2012 : 16) menjelaskan loyalitas pelanggan merupakan kesetiaan pelanggan terhadap perilaku pembelian atas produk atau jasa tertentu. Pemaparan para ahli mengenai definisi loyalitas pelanggan dapat disimpulkan bahwa loyalitas pelanggan adalah keputusan pelanggan untuk tetap konsisten dan setia terhadap pemakaian produk atau jasa tertentu secara berulang dengan jangka waktu yang panjang. Menurut Affan (2020), terdapat empat dimensi yang mempengaruhi loyaslitas pelanggan sebagai berikut. (1) perhatian, (2) kepercayaan, (3) perlindungan dan (4) kepuasan akumulatif. Selain itu, terdapat tiga indikator loyalitas seorang pelanggan menurut Kottler, dkk (2012), antara lain: (a) repeat purchase, (b) retention, (c) referrals.

Menurut Rahmawati (2014) menjelaskan informasi positif yang direkomendasikan oleh pelanggan disebabkan karena kepuasan yang dirasakannya telah melebihi harapan dan kesetiaan untuk tetap memanfaatkan produk pada perusahaan yang sama. Sejalan dengan pendapat dari Fadillah (2015) yang menyatakan jika seorang pelanggan merasa puas dan mampu setia dengan produk atau jasa pada suatu perusahaan, mereka akan membicarakan kepada satu orang saja. Sebaliknya jika semakin tinggi tingkat ketidakpuasan seorang pelanggan bahkan dapat menyebabkan beralihnya pelanggan dengan menggunakan produk atau jasa dari pesaing, mereka akan membicarakan ketidakpuasan dan alasannya beralih ke produk pesaing kepada sepuluh orang. Jadi, komonikasi dari mulut ke mulut dapat bersifat menguntungkan dan merugikan bagi perusahaan. Sejalan dengan hasil penelitian yang dilakukan oleh Casalo, dkk (2008) yang menyatakan bahwa kepuasan pelanggan dan loyalitas pelanggan memiliki efek positif terhadap word of mouth. $\mathrm{H}_{1}$ : Ada pengaruh kepuasan dan loyalitas pelanggan terhadap word of mouth pada pelanggan produk XL Axiata di Kecamatan Buleleng. 
Pengaruh yang dihasilkan oleh kepuasan pelanggan berdampak pada word of mouth (Haditya, 2019). Rahmawati, dkk (2014) yang menyatakan word of mouth yang positif dipengaruhi oleh salah satu faktor penting yaitu kepuasan pelanggan. Kondisi ini disebabkan karna pelanggan yang merasa puas terhadap kinerja suatu produk, dapat memicu mereka untuk merekomendasikan produk tersebut kepada orang lain. Oleh karena itu, dapat dinyatakan pengaruh kepuasan yang positif dapat menunjukkan semakin puasnya seorang pelanggan, maka ia akan melakukan positive word of mouth secara langsung sesuai dengan kesadaran pelanggan itu sendiri. Dan sebaliknya jika kinerja produk atau jasa yang dipilih tidak sesuai dengan harapan pelanggan, maka mereka akan melakukan negative word of mouth yang dapat merugikan perusahaan itu sendiri (Wahyuningsih, dkk, 2010). Teori ini didukung oleh penelitian yang dilakukan Wahyuni, dkk (2018) dan Purwandari (2015) dengan hasil penelitiannya yang menyatakan pengaruh kepuasan pelanggan bernilai positif dan signifikan terhadap word of mouth. $\mathrm{H}_{2}$ : Ada pengaruh kepuasan pelanggan terhadap word of mouth pada pelanggan produk XL Axiata di Kecamatan Buleleng.

Menurut Oliviana (2017) pelanggan yang dikatakan loyal merupakan pelanggan yang tetap setia membeli suatu produk tertentu bahkan dapat merekomendasikannya kepada orang lain. Menurut Titing (2020) menyatakan bahwa pelanggan yang loyal dapat dijadikan sebagai maskot untuk menyebarkan positif word of mouth kepada calon pelanggan. Pelanggan yang loyal merupakan sarana promosi yang paling efektif dan sangat membantu kemajuan perusahaan. Kondisi ini terjadi karena pelanggan yang setia dan tetap bertahan dengan produk tersebut tentu memiliki pengalaman yang baik terhadap suatu produk sehingga dapat merekomendasikan kepada orang lain bahkan dapat menarik pelanggan lain untuk mencoba produk tersebut. Sedangkan pelanggan yang berpaling dengan produk lain tentunya memiliki pengalaman yang kurang baik sehingga tingkat kepuasan yang dirasakan juga rendah, hal ini tentunya menarik pelanggan tersebut untuk menyebarkan pernyataan yang negatif terhadap produk yang digunakannya kepada orang lain. Pernyataan tersebut sejalan dengan penelitian yang dilakukan Laksono, dkk (2016) yang menyatakan bahwa loyalitas memberikan pengaruh yang positif dan signifikan terhadap word of mouth. $\mathrm{H}_{3}$ : Ada pengaruh loyalitas pelanggan terhadap word of mouth pada pelanggan produk XL Axiata di Kecamatan Buleleng.

Berdasarkan pemaparan tersebut, diduga terdapat pengaruh dari variabel kepuasan dan loyalitas pelanggan terhadap variabel word of mouth. Kondisi ini menyebabkan peneliti lebih tertarik membuat penelitian ini untuk menguji "Pengaruh Kepuasan dan Loyalitas Pelanggan Terhadap Word of mouth pada Pelanggan Produk XL Axiata di Kecamatan Buleleng".

Ditinjau dari pemaparan yang ada pada latar belakang dan rumusan masalah penelitian, penelitian ini juga dilakukan dengan tujuan untuk menguji pengaruh : (1) kepuasan dan loyalitas pelanggan terhadap word of mouth pada pelanggan produk $\mathrm{XL}$ Axiata di Kecamatan Buleleng. (2) kepuasan pelanggan terhadap word of mouth pada pelanggan produk XL Axiata di Kecamatan Buleleng. (3) loyalitas pelanggan terhadap word of mouth pada pelanggan produk XL Axiata di Kecamatan Buleleng.

Hasil pada penelitian ini diharapkan dapat memberikan berbagai manfaat baik berupa manfaat teoritis dan manfaat praktis. Manfaat secara teoritis yang diharapkan dalam penelitian ini adalah dapat bermanfaat dalam pengembangan ilmu pengetahuan dibidang manajemen pemasaran khususnya dalam hal yang berkaitan dengan kepuasan dan loyalitas pelanggan terhadap word of mouth. Sedangkan secara praktis diharapkan penelitian ini dapat digunakan oleh pihak PT. XL Axiata Tbk guna memberikan informasi tambahan dan dasar pertimbangan dari kegiatan atau kebijakan perusahaan dalam menentukan kepuasan pelanggan dan mempertahankan loyalitas pelanggan yang nantinya akan direkomendasikan kepada calon pelanggan baru

\section{Metode}

Penelitian ini dilakukan untuk mengetahui pengaruh kepuasan dan loyalitas pelanggan terhadap word of mouth pada pelanggan produk XL Axiata di Kecamatan Buleleng. Sedangkan desain yang digunakan yaitu penelitian kuantitatif kausal. Desain kausal 
dilakukan dengan tujuan untuk menganalisis hubungan antara variabel bebas dan variabel terikat. Penelitian ini menggunakan tiga variabel yang terdiri dari dua variabel bebas yaitu kepuasan pelanggan $\left(X_{1}\right)$ dan loyalitas pelanggan $\left(X_{2}\right)$ serta variabel terikat yaitu word of mouth $(\mathrm{Y})$. Metode pengumpulan data yang dilakukan yaitu dengan pencatatan dokumen dan metode kuisioner. Tahapan dalam desain penelitian kuantitatif kausal ini dimulai dari 1) rumusan masalah, 2) mengkaji teori, 3) merumuskan hipotesi, 4) mengumpulkan data, 5) mengolah data dan 6) menarik kesimpulan.

Subjek penelitian yang digunakan adalah pelanggan $\mathrm{XL}$ Axiata khususnya di Kecamatan Buleleng. Sedangkan kepuasan pelanggan $\left(X_{1}\right)$, loyalitas pelanggan $\left(X_{2}\right)$ dan word of mouth $(\mathrm{Y})$ merupakan objek penelitian. Banyaknya sampel yang digunakan dalam penelitian ini sebanyak 100 responden sesuai dengan jumlah parameter yang diestimasi. Penelitian ini menggunakan teknik purposive sampling, dimana sampel ditentukan secara acak dan menggunakan pertimbangan tertentu dalam memperoleh informasinya, sesuai dengan tujuan atau masalah penelitian

Metode dan teknik analisis data yang digunakan dalam penelitian ini adalah menggunakan analisis regresi linier berganda. Analisis ini digunakan untuk mengetahui besarnya hubungan dan pengaruh baik secara langsung ataupun tidak langsung dari kepuasan pelanggan $\left(X_{1}\right)$ dan loyalitas pelanggan $\left(X_{2}\right)$ terhadap word of mouth $(Y)$ pada pelanggan produk XL Axiata di Kecamatan Buleleng.

\section{Hasil dan Pembahasan}

Hasil penelitian analisis regresi linier berganda yang menguji pengaruh kepuasan dan loyalitas pelanggan terhadap word of mouth pada pelanggan produk XL Axiata di Kecamatan Buleleng dilakukan dengan menggunakan bantuan program SPSS (Statistical Package for Social Science) 22 for Windows. Maka diperoleh hasil penelitian yang dapat dilihat pada Tabel 1.

Tabel 1. Hasil Uji Analisis Regresi Linier Berganda

\begin{tabular}{|c|c|c|c|c|c|}
\hline Parameter & Nilai & $\begin{array}{c}\mathrm{P}- \\
\text { Value }\end{array}$ & $\begin{array}{l}\text { Alpha } \\
(\alpha)\end{array}$ & Keputusan & Simpulan \\
\hline $\operatorname{Ryx}_{1} x_{2}$ & 0,794 & 0,000 & 0,05 & Menolak $\mathrm{H}_{0}$ & $\begin{array}{l}\text { Terdapat pengaruh secara } \\
\text { simultan dari kepuasan } \\
\text { pelanggan dan loyalitas } \\
\text { pelanggan terhadap word } \\
\text { of mouth. }\end{array}$ \\
\hline$R^{2} y x 1 \times 2$ & 0,630 & - & - & & $\begin{array}{l}\text { Menunjukkan besarnya } \\
\text { sumbangan pengaruh } \\
\text { secara bersama-sama dari } \\
\text { kepuasan pelanggan dan } \\
\text { loyalitas pelanggan } \\
\text { terhadap word of mouth } \\
\text { sebesar } 63 \%\end{array}$ \\
\hline$\varepsilon$ & 0,37 & & & & $\begin{array}{ll}\text { Menunjukkan besar } & \text { bengaruh variabel lain } \\
\text { pengas } & \text { sebesar } 37 \%\end{array}$ \\
\hline $\mathrm{Pyx}_{1}$ & 0,430 & 0,000 & 0,05 & Menolak $\mathrm{H}_{0}$ & $\begin{array}{l}\text { Terdapat pengaruh secara } \\
\text { parsial dari kepuasan } \\
\text { pelanggan terhadap word } \\
\text { of mouth }\end{array}$ \\
\hline$P^{2} \mathrm{yx}_{1}$ & 0,185 & - & - & & $\begin{array}{l}\text { Menunjukkan besarnya } \\
\text { sumbangan pengaruh } \\
\text { parsial dari kepuasan } \\
\text { pelanggan terhadap word } \\
\text { of mouth sebesar } 18,5 \%\end{array}$ \\
\hline
\end{tabular}




\begin{tabular}{|c|c|c|c|c|c|}
\hline Parameter & Nilai & $\begin{array}{l}\mathrm{P}- \\
\text { Value }\end{array}$ & $\begin{array}{l}\text { Alpha } \\
(\alpha)\end{array}$ & Keputusan & Simpulan \\
\hline Pyx2 & 0,341 & 0,000 & 0,05 & Menolak $\mathrm{H}_{0}$ & $\begin{array}{l}\text { Terdapat pengaruh secara } \\
\text { parsial dari loyalitas } \\
\text { pelanggan terhadap word } \\
\text { of mouth }\end{array}$ \\
\hline P2yx2 & 0,116 & & & & $\begin{array}{l}\text { Menunjukkan besarnya } \\
\text { sumbangan pengaruh } \\
\text { parsial pada loyalitas } \\
\text { pelanggan terhadap word } \\
\text { of mouth sebesar } 11,6 \%\end{array}$ \\
\hline a & 2,081 & 0,018 & 0,05 & & $\begin{array}{l}\text { Bisa memprediksi tingkat } \\
\text { word of mouth }\end{array}$ \\
\hline b1 & 0,329 & 0,000 & 0,05 & & $\begin{array}{l}\text { Bisa memprediksi tingkat } \\
\text { word of mouth }\end{array}$ \\
\hline b2 & 0,303 & 0,001 & 0,05 & & $\begin{array}{l}\text { Bisa memprediksi tingkat } \\
\text { word of mouth }\end{array}$ \\
\hline
\end{tabular}

Sumber: Output SPSS 22.0 For Windows

Adapun pengaruh pada masing-masing variabel bebas terhadap variabel terikat pada pelanggan produk XL Axiata di Kecamatan Buleleng dapat digambarkan pada Gambar 1.

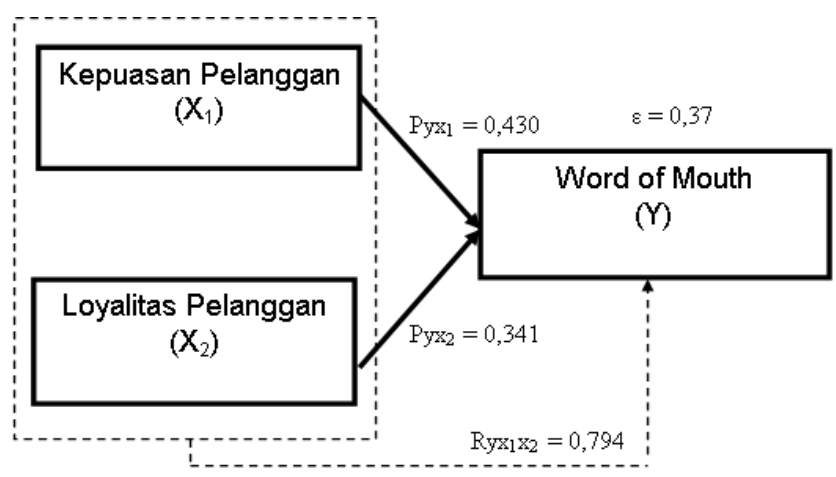

Gambar 1. Struktur Hubungan Pengaruh Kepuasn dan Loyalitas Pelanggan terhadap Word of mouth pada Pelanggan XL Axiata

Besar sumbangan pengaruh variabel $X_{1}$ dan $X_{2}$ terhadp $Y$ dalam penelitian ini dapat dilihat pada Tabel 2.

Tabel 2. Sumbangan pengaruh variabel $X_{1}$ dan $X_{2}$ terhadp $Y$

\begin{tabular}{lll}
\hline \multicolumn{1}{c}{ Keterangan } & \multicolumn{1}{c}{$\begin{array}{c}\text { Besar } \\
\text { Sumbangan }\end{array}$} & $\begin{array}{c}\text { Persentase } \\
(\%)\end{array}$ \\
\hline Pengaruh langsung $\mathrm{X}_{1}$ terhadap $\mathrm{Y}$ & 0,185 & $18,5 \%$ \\
\hline Pengaruh langsung $\mathrm{X}_{2}$ terhadap $\mathrm{Y}$ & 0,116 & $11,6 \%$ \\
\hline Besar pengaruh $\mathrm{X}_{1}$ dan $\mathrm{X}_{2}$ terhadap $\mathrm{Y}$ & 0,630 & $63 \%$ \\
\hline Besar pengaruh faktor lain terhadap $\mathrm{Y}$ & 0,37 & $37 \%$ \\
\hline Total & 1.000 & $100.00 \%$ \\
\hline \multicolumn{3}{c}{ Sumber : Data diolah dengan program SPSS }
\end{tabular}

Hipotesis yang pertama adalah "Ada pengaruh kepuasan dan loyalitas pelanggan terhadap word of mouth pada pelanggan produk XL Axiata di Kecamatan Buleleng. Berdasarkan hasil uji regresi linier berganda pada tabel 2 menunjukkan bahwa kepuasan dan loyalitas pelanggan berpengaruh signifikan terhadap word of mouth. karena $\mathrm{p}$-value 
0,000 kurang dari Alpha $(\alpha)$ 0,05, dengan sumbangan pengaruh sebesar $63 \%$. Sedangkan pengaruh variabel lain diluar variabel kepuasan pelanggan $\left(X_{1}\right)$ dan loyalitas pelanggan $\left(X_{2}\right)$ menunjukkan hasil sebesar $37 \%$. Jadi dapat disimpulkan bahwa variabel kepuasan pelanggan $\left(X_{1}\right)$ dan loyalitas pelanggan $\left(X_{2}\right)$ secara bersama-sama memiliki peran dalam meningkatkan word of mouth $(Y)$.

Hipotesis yang kedua adalah "Ada pengaruh kepuasan pelanggan terhadap word of mouth pada pelanggan produk XL Axiata di Kecamatan Buleleng. Dapat dilihat pada tabel 2 menunjukkan bahwa kepuasan pelanggan berpengaruh signifikan terhadap word of mouth. karena $p$-value 0,000 lebih kecil Alpha ( $\alpha$ ) 0,05, dengan sumbangan pengaruh sebesar $18,5 \%$. Sehingga kesimpulannya yaitu variabel kepuasan pelanggan $\left(X_{1}\right)$ memiliki peran dalam meningkatkan word of mouth $(\mathrm{Y})$.

Hipotesis yang ketiga adalah "Ada pengaruh loyalitas pelanggan terhadap word of mouth pada pelanggan produk XL Axiata di Kecamatan Buleleng. Hasil pada tabel 2 menunjukkan bahwa loyalitas pelanggan berpengaruh signifikan terhadap word of mouth. karena p-value 0,000 lebih rendah Alpha ( $\alpha$ ) 0,05, dengan sumbangan pengaruh sebesar $11,6 \%$. Hasil tersebut menunjukkan bahwa variabel loyalitas pelanggan $\left(\mathrm{X}_{2}\right)$ memiliki peran dalam meningkatkan word of mouth $(\mathrm{Y})$.

Berdasarkan hasil penelitian yang dilakukan menunjukkan bahwa kepuasan dan loyalitas pelanggan terhadap word of mouth memiliki pengaruh yang signifikan. Hal ini menunjukkan bahwa tingkat word of mouth yang dilakukan pelanggan memiliki keterkaitan dengan kepuasan dan loyalitas pelanggan. Oleh karena itu, pihak perusahaan hendaknya mampu memperhatikan apa yang menjadi kebutuhan dan keinginan pelanggan terkait produk XL Axiata, sehingga para pelanggan mampu menceritakan pengalaman positifnya guna menarik minat konsumen lain untuk ikut memanfaatkan produk atau jasa yang dipilihnya.

Hasil uji pada penelitian tersebut memaparkan bahwa kepuasan pelanggan terhadap word of mouth memiliki pengaruh yang positif dan signifikan. Kondisi ini berarti kepuasan pelanggan dapat mempengaruhi tingkat word of mouth. Dapat diketahui bahwa semakin tinggi tingkat kepuasan pelanggan maka tingkat word of mouth yang dilakukan oleh pelanggan produk XL Axiata juga akan semakin meningkat. Pihak perusahaan hendaknya mampu memenuhi kebutuhan dan keinginan pelanggan dengan optimal seperti meningkatkan kualitas baik dari segi pelayanan, produk dan harga.

Penelitian yang dilakukan menyatakan hasil bahwa loyalitas pelanggan memiliki pengaruh yang positif dan signifikan terhadap word of mouth. Sehingga dapat ditunjukkan bahwa loyalitas pelanggan mampu mempengaruhi tingkat word of mouth. Semakin tinggi kesetiaan dari pelanggan maka tingkat penyebaran yang dilakukan melalui word of mouth yang dilakukan oleh pelanggan produk XL Axiata juga akan semakin meningkat. Pihak perusahaan hendaknya menjaga dan mempertahankan kesetiaan pelanggan dengan baik. Seperti dengan memberikan diskon atau bonus pada setiap pembelian produk XL Axiata kepada pelanggan yang setia

\section{Simpulan dan Saran}

Pemaparan hasil uji dan pembahasan yang dilakukan dalam penelitian ini, menghasilkan kesimpulkan bahwa: (1) Kepuasan dan Loyalitas Pelanggan memiliki pengaruh yang signifikan terhadap word of mouth. Dapat diartikan jika tingkat kepuasan dan loyalitas pelanggan tinggi maka tingkat word of mouth juga akan meningkat. (2) Kepuasan pelanggan memiliki pengaruh yang positif dan signifikan terhadap word of mouth. Hal ini terjadi apabila tingkat kepuasan pada pelanggan tinggi maka tingkat penyebaran yang dilakukan melalui word of mouth juga akan meningkat. (3) Loyalitas pelanggan memiliki pengaruh yang positif dan signifikan terhadap word of mouth. kondisi ini berarti apabila loyalitas pelanggan tinggi maka word of mouth juga akan mengalami peningkatan.

Bagi peneliti selanjutnya, diharapkan dapat lebih mengembangkan penelitiannya seperti dengan menambahkan variabel-variabel lain yang mempengaruhi word of mouth dan lebih memperbanyak teori-teori yang terdapat dijurnal bersinta sehingga referensi tersebut lebih diakui kebenarannya. Selain itu, peneliti juga diharapkan dapat menggunakan teknik 
analisis data dan subjek yang lain, agar mampu menambah pengetahuan ilmu pengetahuan dan dapat menjadi acuan pada penelitian-penelitian selanjutnya khususnya pada manajemen pemasaran

Untuk manajer perusahaan utamanya PT XL Axiata Tbk, diharapkan dapat lebih memperhatikan terkait kepuasan pelanggan yang diharapkan serta mampu mempertahankan tingkat loyalitas pelanggan sehingga dapat menarik para pelanggan untuk menyebarkan word of mouth yang positif dan mampu menarik perhatian calon pelanggan yang baru.

\section{Daftar Pustaka}

Affan, dkk. 2020. "Pengaruh Kualitas Jasa dan Keputusan Konsumen Terhadap Loyalitas Konsumen Pada PT Sekawan Jaya Lestari". Journal of Business and Economics Research (JBE), Vol 1, No 3 (Hal. 226-232).

Anggita, Laras. 2019. Pengaruh Kualitas Layanan terhadap Kepuasan, Loyalitas dan Word of Mouth pada Peserta Bpjs Ketenagakerjaan Cabang Bandar Lampung. Tesis (tidak diterbitkan) Fakultas Ekonomi Dan Bisnis, Universitas Lampung.

Anita, dkk. 2015. "Pengaruh Kualitas Pelayanan Terhadap WOM Melalui Kepuasan Pada PT. Sarana Dewata Courier". E-Jurnal Manajemen Unud, Vol. 4, No. 8 (Hal 21922209).

Barry. 2015. "Modelling Customer Statisfaction and Word of Mouth Restaurant Patronage in Korea". Jurnal of Service Marketing, Vol 19, No 3 (Hal 133-139).

Casalo, dkk. 2008. "The Role of Satisfaction and Website Usability in Developing Customer Loyalty and Positive Word of Mouth in the E-Banking Services". International Journal of Bank Marketing.

Dewi, Diah. 2019. "Layanan Data Meningkat, XL Terus Perkuat Jaringan”. Tersedia pada http://www.balipost.com/news/2019/07/22/81629/Layanan-Data-Meningkat,XLTerus...html. (Diakses pada 21 April 2020).

Fadillah. 2015. "Model Komunikasi "Wom" Sebagai Strategi Pemasaran Efektif". Humanika, Vol. 15, No. 1 (Hal 66-74).

Finanda, dkk. 2017. "Pengaruh Word of Mouth dan Brand Image Terhadap Keputusan Penggunaan Salon Kecantikan pada Konsumen Miloff Beauty Bar". Jurnal IImiah WIDYA Ekonomika, Vol 1, No 2 (Hal 134-140).

Fitriani, dkk. 2018. "Pengaruh Satisfaction, Loyalty dan Trust terhadap Wom Behaviour pada Pelanggan Carrefour Lebak Bulus, Jakarta". Jurnal Wira Ekonomi Mikroskil, Vol. 8, No. 1 (halm 49-60)

Fleming, N. 2016. The customer Loyalti Loop: The Science Behind Creating Great Experiences and Lasting Impressions. First edition. New Jersey: Career press.

Gerson, R.F. 2010. Mengukur Kepuasan Pelanggan: Panduan Menciptakan Pelayanan Bermutu. Edisi Pertama. Jakarta : PPM - Bisnis 2030.

Griffin, J. 2012. Customer Loyalty : How To Earn It, How To Keep It, Completely Revised \& Update Edition. San Fransisco: Jossey-Bass Publishing.

Haditya, S. dkk. 2019. "The Influence Of Marketing Mix, Perceived Risk, And Satisfaction On Word Of Mouth In Xyzclinic". Journal of Consumer Sciences, Vol 04, No 01, (hlm. 1324).

Irawan, Handi. 2008. Indonesia Customer Satisfaction. Jakarta: PT. Alex Media Computindo

Joesyiana, Kiki. 2018. "Pengaruh Word of Mouth Terhadap Keputusan Pembelian Konsumen pada Media Online Shop Shopee di Pekan Baru”. Jurnal Valuta, Volume 4, No 1 (Hal 71-85). 
Kotler, dkk. 2012, Manajemen Pemasaran. Jilid I Edisi ke 12. Jakarta: Erlangga.

Kristianto. 2011. Psikologi Pemasaran. Yogyakarta : CAPS.

Laksono. 2016. Pengaruh Kualitas Layanan terhadap Kepuasan, Loyalitas dan Word of Mouth pada Pusat Training Perbankan Yogyakarta. Tesis (tidak diterbitkan) Fakultas Ekonomi, Universitas Islam Indonesia Yogyakarta.

Liao, dkk. 2010. "The Impacts of Brand Trust, Customer Satisfaction, and Brand Loyalty on Word-of-Mouth". Industrial Engineering and Engineering Management. Hal 1319-1323.

Oliviana, dkk. 2017. "Pengaruh Brand Image dan WOM (Word Of Mouth) Terhadap Loyalitas Konsumen pada RM. Dahsyat Wanea". Jurnal EMBA. Volume 5, No 2 (Hal 1081-1092).

Purwandari, Suci. 2015. "Pengaruh Kualitas Layanan, Citra, Lokasi dan Kualitas Pengajar Terhadap Word of Mouth dengan Kepuasan Sebagai Pemediasi”. Jurnal Sainstech Politeknik Indonesia Surakarta, Volume 2, No 4 (Hal 55-69)

Puspa, Rani. 2014. "Pengaruh Kualitas Layanan terhadap Kepuasan Pelanggan serta Dampaknya pada Loyalitas dan Words of Mouth". JBBE, Vol.07, No.2 (Hal 49-57).

Rahmawati, dkk. 2014. "Pengaruh Kepuasan dan Loyalitas Pelanggan terhadap Word of Mouth pada Pelanggan Honda Motor di Surabaya". Journal of Business and Banking, Vol. 4, No. 1 (Halm 15-30).

Sudarso, dkk. 2018, "Pengaruh Kualitas Produk dan Harga terhadap Kepuasan Konsumen PT XL Axiata Tbk (Studi Kasus Mahasiswa Politeknik Negeri Medan). Hal (1-9).

Sukarelawanto. 2019. "Libur Akhir Tahun, Layanan Data Telkomsel \& XL Melonjak di Bali Nusra".

Tjiptono, F, dkk. 2012. Pemasaran Strategik. Edisi Kedua. Yogyakarta: Andi.

Tersedia pada https://bali.bisnis.com/read/20190109/538/876967/libur-akhir-tahunlayanan-data-telkomsel-xl-melonjak-di-bali-nusra. (Diakses pada 21 April 2020)

Titing, dkk. 2020. "Pengaruh Kepuasan Pelanggan dan Loyalitas Pelanggan terhadap Word of Mouth (Studi Kasus di Cafe Come on Coffe Pomalaa)". Vol. 10, No. 1 (Hal 34-47).

Wahyuni, dkk. 2018. "Peran Kepuasan Pelanggan dalam Memediasi Kualitas Layanan Terhadap Word of Mouth". E-Jurnal Manajemen Unud, Vol 7, No 5 (Hal 2823-2855).

Wahyuningsih, dkk. 2010. "The Effect of Customer Satisfaction on Behavioral Intentions: A Study on Consumer Behavior of Car Insurance Consumers in Melbourne, Australia". Jurnal Manajemen Bisnis, Vol. 3, No. 1 (Hal 1-16).

Widiyanesti, dkk. 2016. "Pengaruh Kualitas Pelayanan Terhadap Kepuasan Konsumen di Rock N Roll Haircutting Bandung". E-Proceeding of Management, Vol.3, No.2 